\title{
Associations of acetyl-coenzyme A carboxylase $\alpha$, stearoyl-coenzyme A desaturase, and lipoprotein lipase genes with dairy traits in Alpine goats
}

\author{
P. Crepaldi, ${ }^{* 1}$ L. Nicoloso, ${ }^{*}$ B. Coizet, ${ }^{*}$ E. Milanesi, ${ }^{*}$ G. Pagnacco, ${ }^{*}$ P. Fresi, † C. Dimauro, $\ddagger$ \\ and N. P. P. Macciottał \\ *Università degli Studi di Milano, Dipartimento di Scienze Veterinarie e Sanità Pubblica, via Celoria 10, 20133 Milan, Italy \\ †Associazione Nazionale della Pastorizia, Via Palmiro Togliatti 1587, 00155 Rome, Italy \\ łUniversità di Sassari, Dipartimento di Agraria, Sezione Scienze Zootecniche, Via de Nicola 9, 07100 Sassari, Italy
}

\begin{abstract}
Milk yield and composition are of great economic importance for the dairy goat industry. The identification of genes associated with phenotypic differences for these traits could allow for the implementation of gene-assisted selection programs in goats. Associations between polymorphisms at 3 candidate genes and milk production traits in Alpine goats farmed in Italy were investigated in the present research. Considered genes were acetyl-coenzyme A carboxylase $\alpha(A C A C A)$, the major regulatory enzyme of fatty acid biosynthesis; stearoyl-coenzyme A desaturase $(S C D)$, involved in the biosynthesis of monounsaturated fatty acids in the mammary gland; and lipoprotein lipase $(L P L)$, which plays a central role in plasma triglyceride metabolism. An approach somewhat similar to the granddaughter design for detecting quantitative trait loci in dairy cattle was followed. Effects of genotypes of a sample of 59 Alpine bucks on phenotypes of their 946 daughters raised in 75 flocks were investigated. Data comprised 13,331 daily records for milk yields (L/d), fat and protein yields $(\mathrm{kg} / \mathrm{d})$, and fat and protein contents (\%) of 2,200 lactations. Population genetics parameters were calculated and associations between milk production traits and 10 single nucleotide polymorphisms (SNP) at the 3 genes were tested. Two markers at the $A C A C A$, 1 for the $S C D$ and 1 at the $L P L$ locus, deviated significantly from the Hardy-Weinberg equilibrium, with an observed heterozygosity lower than expected. Flock, age of the goat, kidding season, and stage of lactation affected all traits considered, except fat percentage. Three SNP were found to be significantly associated with milk production traits. The SNP located on the $A C A C A$ gene showed an effect on milk yield, with daughters of TT bucks having an average test-day milk yield of about 0.3 to $0.25 \mathrm{~L} / \mathrm{d}$ lower than the other 2 genotypes. The marker on the $L P L$ locus was highly
\end{abstract}

Received July 25, 2012.

Accepted November 8, 2012.

${ }^{1}$ Corresponding author: paola.crepaldi@unimi.it associated with milk yield, with the largest values for CC daughters (about 0.50 L more than GG). The TGT deletion located on the untranslated region of the $S C D$ gene showed significant effects on average milk and protein yields. The homozygote-deleted genotype had values about $0.5 \mathrm{~L} / \mathrm{d}$ and $16 \mathrm{~g} / \mathrm{d}$ lower for milk and protein daily yield, respectively, compared with the TGT/TGT genotype. Differences between genotypes were quite constant across most of the lactation. Associations found in the present study, which should be tested in a larger sample, especially for those markers that show rare genotypes, may offer useful indications for the genetic improvement of dairy traits in goats.

Key words: goat milk trait, candidate gene, single nucleotide polymorphism effect

\section{INTRODUCTION}

The identification of mutations in genes found to affect dairy traits in cattle (Grisart et al., 2002; Cohen Zinder et al., 2005; Mele et al., 2007) has opened interesting perspectives for the implementation of geneassisted selection schemes. Fat and protein yield and composition are traits of great economic importance in the dairy goat industry, whose milk is mainly destined for cheese processing. This species is considered of limited importance in the leading world countries for animal production. However, it plays a relevant role for smallholders in ecologically marginal areas such as dry lands and mountains(FAO, 2007).

The improvement of milk quality traits in goats by conventional breeding schemes is hampered by the costs for measuring phenotypes. Actually, few breeding programs exist for this species. The identification of genes affecting composition traits could, therefore, be useful for implementing gene-assisted selection programs able to partly overcome the above-mentioned drawbacks. Associations between polymorphisms at casein loci and milk composition have been extensively studied in goats (Ibeagha-Awemu et al., 2008). In particular, several causative mutations at the $\alpha_{\mathrm{s} 1}$-CN locus 
associated with the content of this protein in milk have been detected; also, polymorphisms at the $\mathrm{\kappa}$-CN locus have been associated with milk quality and cheese yield (Chiatti et al., 2007; Caravaca et al., 2011). The genetic background of fat has been less investigated due to the assessed influence of the diet in controlling milk fat content and FA composition (Jenkins and McGuire, 2006).

Milk fat synthesis is a complex process that involves several enzymes, some of which have been characterized at the molecular level in goats. Acetyl-coenzyme A carboxylase $\alpha$ (ACACA) is the major regulatory enzyme of FA biosynthesis. It is considered the ratelimiting step in de novo synthesis in animal tissues. The $A C A C A$ gene was found to be markedly upregulated during lactation in cattle (Bionaz and Loor, 2008). In goats, the coding sequence from exon 3 to 46 has been characterized by sequencing $5.5 \mathrm{~kb}(78 \%)$ of the cDNA (Badaoui et al., 2007). A silent SNP associated with milk fat content has been identified on exon 45 (C5493T) in 5 Spanish breeds. Signorelli et al. (2009) found $3 \mathrm{SNP}$ in a portion of the $5^{\prime}$ untranslated region (UTR) that encodes promoter III, which acts in the regulation of mammary gland transcripts. These markers were found to be associated with fat yield.

The stearoyl-CoA desaturase $(\boldsymbol{S C D})$ gene encodes an integral membrane protein of the endoplasmic reticulum that plays a central role in MUFA synthesis (Ntambi and Miyazaki, 2004). Most of the conjugated linoleic acid in ruminant milk is synthesized in the mammary gland by the action of SCD on circulating vaccenic acid (Bauman et al., 2006). Associations between $S C D$ polymorphisms and FA composition of meat and milk fat (Mele et al., 2007; Moioli et al., 2007a; Ohsaki et al., 2009) and milk and protein yield (Macciotta et al., 2008 ) in cattle have been reported. The $S C D$ gene has been mapped on goat chromosome 26. The mRNA has been sequenced (Bernard et al., 2001; Yahyaoui et al., 2002). Two SNP have been reported in exon 5 (Yahyaoui, 2003; Yahyaoui et al., 2003) and a deletion of a nucleotide triplet has been detected in the $3^{\prime} \mathrm{UTR}$ (Bernard et al., 2001). Single nucleotide polymorphisms identified in exon 3 , intron 3 , intron 4 , and exon 6 have been reported to be associated with growth traits in Chinese goat breeds (Zhang et al., 2010; Chen et al., 2011).

The lipoprotein lipase $(\boldsymbol{L P L})$ gene encodes for the rate-limiting enzyme in the hydrolysis of the triglyceride core of circulating triglyceride-rich lipoproteins, chylomicrons, and very low-density lipoproteins. In goats, the sequencing of the $L P L$ cDNA allowed the identification of 2 SNP: a missense mutation responsible for a Ser $>$ Thr amino acid substitution at position 17 of the signal peptide and a $\mathrm{C}$ to $\mathrm{T}$ substitution in the $3^{\prime} \mathrm{UTR}$ of the gene (Badaoui et al., 2007). Moreover, the same authors found an association of the missense SNP with milk fat content.

One of the best-producing dairy goat breeds in Italy and in the world is the Alpine breed. The registered Italian Alpine population consists of 15,145 goats. It is the second goat breed of the country in terms of the number of farmed animals. In 2011, the average milk yield per goat in $210 \mathrm{~d}$ was $500 \mathrm{~L}$, with 3.49 and $3.33 \%$ fat and protein content, respectively. Most of the milk is destined for cheese processing. Polymorphisms in the 3 considered genes with favorable effects on milk yield and, especially, composition could, therefore, be useful for the genetic improvement of the breed.

A common issue for association studies in small ruminants is the limited size of the sample of animals considered. In the early 1990s, the granddaughter design was proposed to increase the size of population involved in the analysis (Weller et al., 1990). In this study, the effect of the genotype of a sample of Alpine bucks at the 3 candidate loci was investigated on the phenotype of their daughters. Actually, such an approach could be seen as something between a daughter (2 generations are considered) and a granddaughter (only sires are genotyped, not animals with performances) design. The aim of the present research was to investigate possible associations between polymorphisms at the 3 candidate genes ( $A C A C A, S C D$, and $L P L)$ and milk production traits in Alpine goats farmed in Italy.

\section{MATERIALS AND METHODS}

\section{DNA Extraction and SNP Genotyping}

Hair samples from 59 Alpine bucks were collected. Genomic DNA was extracted using the tissue and hair extraction kit (Promega Corp., Madison, WI).

Based on information obtained by in silico analysis of the $A C A C A$ locus, primer pairs were designed to amplify exon 14, showing an in silico SNP identified by the alignment of the following sequences: DQ370054 (Badaoui et al., 2007) and Z17803 (Travers and Barber, 1993) and the genomic region spanning exon 44 to 45 to detect the silent SNP previously reported (Badaoui et al., 2007).

For the $S C D$ gene, 7 primer pairs amplifying exons 1 to 6 and a partial $3^{\prime} \mathrm{UTR}$ sequence were designed. For the $L P L$ gene, 9 primer pairs amplifying exons 1, $2,7,8,9$, and a 3 'UTR sequence were designed. Single nucleotide polymorphism discovery was carried out by aligning sequences of genomic DNA of 12 goats (P. Crepaldi, L. Nicoloso, and E. Milanesi, unpublished data).

Genotyping of the 9 SNP and 1 indel identified was carried out in outsourcing, exploiting the KASPar 
Table 1. Single nucleotide polymorphism information

\begin{tabular}{lllllll}
\hline Gene name $^{1}$ & SNP name $^{2}$ & Location & SNP & AA change & Reference & SeqRef-SNP identification $^{3}$ \\
\hline$A C A C A$ & ACACAex14_CT & Exon 14 & C/T & No & Our work & rs155505584 \\
$A C A C A$ & ACACAex45_CT & Exon 45 & C/T & No & Badaoui et al. (2007) & DQ370054-C5493T \\
$A C A C A$ & ACACAex46_1CT & Exon 46 & C/T & No & Our work & ss522928245 \\
$L P L$ & LPLex1G50C & Exon 1 & G/C & Ser36 to Thr & Badaoui et al. (2007) & DQ370053-G50C \\
$L P L$ & LPLint7_CT & Intron 7 & C/T & & Our work & s5522928251 \\
$S C D$ & SCDex2_AG & Exon 2 & A/G & No & Our work & rs1555055578 \\
$S C D$ & SCDex3_AG & Exon 3 & A/G & Val109 to Met & Chen et al. (2011) & AF325499-EX3_15G > A \\
$S C D$ & SCDex5_CT & Exon 5 & C/T & No & Our work & rs155505581 \\
$S C D$ & SCDex5_GT & Exon 5 & G/T & No & Yahyaoui et al. (2003) & AF339909 \\
$S C D$ & SCD3UTR_delTGT & 3'UTR & $-/ T G T$ & & Bernard et al. (2001) & AF325499 \\
\hline
\end{tabular}

${ }^{1} A C A C A=$ acetyl-CoA carboxylase $\alpha ; L P L=$ lipoprotein lipase; $S C D=$ stearoyl-CoA desaturase.

${ }^{2} \mathrm{ex}=$ exon; int $=$ intron; UTR $=$ untranslated region; del $=$ deletion.

${ }^{3}$ Sequenced reference (SeqRef) identification in the National Center for Biotechnology Information (NCBI) database (http://www.ncbi.nlm.nih. $\operatorname{gov} /)$.

SNP genotyping system developed and patented by KBioscience (http://www.kbioscience.co.uk). The SNP analyzed are described in Table 1.

\section{Milk Recording Data}

Data comprised 13,331 daily records for milk yields $(\mathrm{L})$, fat and protein yields $(\mathrm{kg} / \mathrm{d})$, and fat and protein contents (\%) of 2,220 lactations recorded on 946 goats, daughters of the 59 above-described bucks. Phenotypes were recorded by the Italian Association of Animal breeders in the period March 2002 to February 2010. Goats were farmed in 75 flocks located mainly in the north of Italy. The average number of daughters per buck was 16.8 (minimum 3, maximum 79). Average daily yields were $2.49 \pm 1.12 \mathrm{~L}, 76.8 \pm 48.8 \mathrm{~g}$, and $78.5 \pm 37.6 \mathrm{~g}$ for milk, fat, and protein, respectively. Average fat and protein percentages were $3.12 \pm 1.38$ and $3.19 \pm 0.81 \%$, respectively.

\section{Statistical Analysis}

Population genetics parameters were calculated using PowerMarker v3.25 (http://statgen.ncsu.edu/powermarker; Liu and Muse, 2005). In particular, minor allele frequency, expected and observed heterozygosity, and Hardy-Weinberg equilibrium exact $P$-values were calculated.

Associations between milk production traits and each single SNP at the 3 candidate genes were tested using the following mixed linear model:

$$
\begin{gathered}
Y_{i j k l m n o p q}=\mu+\mathrm{FLOCK}_{i}+\mathrm{bTD}+\mathrm{DIM}_{j}\left(\mathrm{SNP}_{k}\right) \\
+\mathrm{SNP}_{\mathrm{k}}+\mathrm{SEA}_{l}+\mathrm{AGE}_{m}+\mathrm{KIDS}_{n} \\
+G_{o}\left(\mathrm{SNP}_{\mathrm{k}}\right)+S_{p}\left(\mathrm{FLOCK}_{i}\right)+e
\end{gathered}
$$

where $Y_{i j k l m n o p q}=$ milk $(\mathrm{L} / \mathrm{d})$, fat, or protein $(\mathrm{kg} / \mathrm{d})$ yield and fat and protein content (\%) test-day (TD) record $o$ of goat $n ; \mu=$ overall mean; LLOCK $_{i}=$ random effect of the flock ( 75 levels); bTD $=$ covariable represented by the date of the milk sample collection; $\mathrm{DIM}_{j}=$ fixed effect of the stage of lactation (10 intervals of $30 \mathrm{~d}$ each); $\mathrm{SNP}_{k}=$ fixed effect of the SNP genotype of the sire (3 levels); $\mathrm{SEA}_{l}=$ fixed effect of the kidding season (4 levels); $\mathrm{AGE}_{m}=$ fixed effect of the age of the goat at kidding in years ( 7 levels: 1 to 6 and $>6) ; \operatorname{KIDS}_{n}=$ fixed effect of number of kids at parturition (3 levels: 1 , 2 , and $>2) ; G_{o}=$ random effect of the goat (946 levels); $S_{p}\left(\mathrm{FLOCK}_{i}\right)=$ random effect of the sire (59 bucks) nested within flock; and $e=$ random residual.

The fixed effect of the sire SNP genotype allowed for the estimation of its effect on dairy traits of the daughters averaged across the whole lactation. Being the effect evaluated on progeny phenotype, it was expected to be halved. The DIM factor nested within SNP was included in the model to estimate lactation curves of the different genotypes (Stanton et al., 1992). The random effect of goat nested within SNP genotype was included to account for individual variability. A random sire effect was also considered to account for the effect of the buck, even though its (co)variance was not structured with the relationship matrix due to the limited availability of parentage information. Moreover, it was considered nested within the flock because most bucks have daughters only in 1 flock. Random effects of model 1 were assumed to be normally distributed with (co)variance matrices for flock $\left(\mathbf{I} \sigma_{F}^{2}\right)$, goat $\left(\mathbf{I} \sigma_{g}^{2}\right)$, sire $\left(\mathbf{I} \sigma_{B}^{2}\right)$, and residual $\left(\mathbf{I} \sigma_{e}^{2}\right)$. Statistical significance of the SNP effect was tested against variance of goat nested within SNP genotype (Littell et al., 1998). Being that each SNP was tested separately, the level of significance was corrected gene wide using the Bonferroni adjust- 
Table 2. Population genetics parameters: buck genotype frequencies, minor allele frequencies (MAF), observed and expected heterozygosity (Het obs and Het exp, respectively), and Hardy-Weinberg (HW) equilibrium exact $P$-values at the investigated SNP

\begin{tabular}{|c|c|c|c|c|c|c|c|}
\hline \multirow{2}{*}{$\frac{\mathrm{SNP}^{1}}{\mathrm{ACACAex14 \_ CT}}$} & \multicolumn{3}{|c|}{ Genotype and frequency } & \multirow{2}{*}{$\begin{array}{c}\begin{array}{c}\text { Allele and } \\
\text { MAF }\end{array} \\
\mathrm{T}\end{array}$} & \multirow[t]{2}{*}{ Het obs } & \multirow[t]{2}{*}{ Het exp } & \multirow[t]{2}{*}{$\begin{array}{c}\mathrm{HW} \text { exact } \\
P \text {-value }\end{array}$} \\
\hline & $\mathrm{CC}$ & $\mathrm{CT}$ & $\mathrm{TT}$ & & & & \\
\hline & 0.625 & 0.375 & - & 0.1875 & 0.375 & 0.305 & 0.186 \\
\hline \multirow[t]{2}{*}{ ACACAex45_CT } & $\mathrm{CC}$ & $\mathrm{CT}$ & $\mathrm{TT}$ & $\mathrm{T}$ & & & \\
\hline & 0.589 & 0.286 & 0.125 & 0.268 & 0.286 & 0.392 & $0.044^{*}$ \\
\hline \multirow[t]{2}{*}{ ACACAex46_1CT } & $\mathrm{CC}$ & $\mathrm{CT}$ & $\mathrm{TT}$ & C & & & $\mathrm{T}$ \\
\hline & 0.069 & - & 0.931 & 0.069 & 0.00 & 0.128 & $0.002 *$ \\
\hline \multirow[t]{2}{*}{ LPLex1_G50C } & $\mathrm{CC}$ & $\mathrm{CG}$ & GG & C & G & G & G \\
\hline & 0.02 & 0.216 & 0.764 & 0.128 & 0.216 & 0.222 & 1 \\
\hline \multirow[t]{2}{*}{ LPLint7_CT } & $\mathrm{CC}$ & $\mathrm{TC}$ & $\mathrm{TT}$ & C & & & \\
\hline & 0.074 & 0.17 & 0.756 & 0.159 & 0.170 & 0.269 & $0.016^{*}$ \\
\hline \multirow[t]{2}{*}{ SCDex2_AG } & AA & GA & GG & G & & & \\
\hline & 0.455 & 0.436 & 0.109 & 0.327 & 0.436 & 0.440 & 1 \\
\hline \multirow[t]{2}{*}{ SCDex3_AG } & AA & GA & GG & G & & & \\
\hline & 0.353 & 0.53 & 0.117 & 0.382 & 0.529 & 0.472 & 0.37 \\
\hline \multirow[t]{2}{*}{ SCDex5_CT } & $\mathrm{CC}$ & $\mathrm{CT}$ & $\mathrm{TT}$ & $\mathrm{T}$ & & & \\
\hline & 0.444 & 0.40 & 0.156 & 0.356 & 0.400 & 0.458 & 0.475 \\
\hline \multirow[t]{2}{*}{ SCDex5_GT } & GG & GT & $\mathrm{TT}$ & $\mathrm{T}$ & & & \\
\hline & 0.636 & 0.25 & 0.114 & 0.239 & 0.250 & 0.363 & $0.036^{*}$ \\
\hline \multirow[t]{2}{*}{ SCD3UTR_delTGT } & -- & $-\mathrm{TGT}$ & TGTTGT & - & & & \\
\hline & 0.152 & 0.522 & 0.326 & 0.413 & 0.522 & 0.485 & 0.755 \\
\hline
\end{tabular}

${ }^{1} \mathrm{ACACA}=$ acetyl-CoA carboxylase $\alpha ; \mathrm{LPL}=$ lipoprotein lipase; $\mathrm{SCD}=$ stearoyl-CoA desaturase; $\mathrm{ex}=$ exon; int $=$ intron; UTR $=$ untranslated region; del $=$ deletion

ment. Pairwise comparisons between different levels of fixed effects were performed using a Bonferroni-adjusted test.

Average gene substitution effect $(\alpha)$ was calculated using a model with the same structure of model 1 but with the gene effect treated as a covariable. The coding of the 3 genotypes $(0,1$, and 2$)$ was based on the number of copies of the first allele in alphabetical order. Moreover, an interaction between alleles at the SNP locus was included to account for possible dominance effects (Banos et al., 2008; Pauciullo et al., 2012).

Variance associated with the SNP genotype $\left(\sigma_{S N P}^{2}\right)$ was estimated by running a model with the same structure of model 1 but with the SNP treated as random. Thus, a variance component associated with the SNP locus was estimated. Contributions of the SNP locus $\left(r_{S N P}^{2}\right)$ and goat $\left(r_{g}^{2}\right)$ to the total phenotypic variance of the trait considered were calculated as

$$
r_{S N P}^{2}=\frac{\sigma_{S N P}^{2}}{\sigma_{F}^{2}+\sigma_{S N P}^{2}+\sigma_{g}^{2}+\sigma_{B}^{2}+\sigma_{e}^{2}}
$$

and

$$
r_{g}^{2}=\frac{\sigma_{g}^{2}}{\sigma_{F}^{2}+\sigma_{g}^{2}+\sigma_{S N P}^{2}+\sigma_{B}^{2}+\sigma_{e}^{2}} .
$$

\section{RESULTS}

Population parameters for the 10 polymorphisms are reported in Table 2. Two markers at the ACACA, 1 for the $S C D$, and 1 at the $L P L$ locus deviated significantly from the Hardy-Weinberg equilibrium. All of them showed an observed heterozygosity lower than the expected.

Flock, age of the goat, kidding season, and stage of lactation affected all traits considered $(P<0.001)$ except age at kidding for fat percentage. Number of kids at parturition affected only yield traits. Both yield and composition traits tended to increase with age at parturition. The highest values were reached at 3 to 4 yr, with least squares means (SE) of $2.28(0.05) \mathrm{L} / \mathrm{d}$ for milk, $76.7(2.0) \mathrm{g} / \mathrm{d}$ for fat content, and $74.8(1.5) \mathrm{g} / \mathrm{d}$ for protein content respectively. Winter kidding had the highest daily yields $(2.25 \pm 0.04 \mathrm{~L}$ of milk/d, $75.1 \pm$ $1.5 \mathrm{~g}$ of fat/d, and $72.6 \pm 1.4 \mathrm{~g}$ of protein/d). The trend across kidding seasons was less defined for fat and protein percentages. Goats with 2 or more kids at parturition produced more milk, fat, and protein $(2.17$ $\pm 0.07 \mathrm{~L} / \mathrm{d}, 69.2 \pm 3.0 \mathrm{~g} / \mathrm{d}$, and $72.1 \pm 2.5 \mathrm{~g} / \mathrm{d}$, respectively, for goats with more than 2 kids, and $1.9 \pm 0.05$ $\mathrm{L} / \mathrm{d}, 66.3 \pm 2.1 \mathrm{~g} / \mathrm{d}$, and $64.1 \pm 1.8 \mathrm{~g} / \mathrm{d}$, respectively, for goats with 2 kids) compared with those with 1 kid $(1.81 \pm 0.05 \mathrm{~L} / \mathrm{d}, 63.3 \pm 2.1 \mathrm{~g} / \mathrm{d}$, and $60.7 \pm 1.8 \mathrm{~g} / \mathrm{d}$, respectively). 
Table 3. Least squares means and SE (in parentheses) of the different SNP genotypes at the acetyl-CoA carboxylase $\alpha(A C A C A)$, stearoyl-CoA desaturase $(S C D)$, and lipoprotein lipase $(L P L)$ loci significantly associated with milk (MY), fat (FY), and protein (PY) yields, and fat (FP) and protein (PP) percentages in the Alpine goats (number of daughters phenotype) estimated by model 1

\begin{tabular}{|c|c|c|c|c|c|}
\hline $\mathrm{SNP}^{1}$ & Goats (no.) & MY (L/d) & PY (g/d) & $\mathrm{FP}(\%)$ & PP (\%) \\
\hline \multicolumn{6}{|c|}{ ACACAex45_CT } \\
\hline $\mathrm{CC}$ & 1,078 & $1.93(0.16)^{\mathrm{A}}$ & & & \\
\hline $\mathrm{CT}$ & 513 & $1.90(0.17)^{\mathrm{A}}$ & & & \\
\hline $\mathrm{TT}$ & 209 & $1.63(0.18)^{\mathrm{B}}$ & & & \\
\hline \multicolumn{6}{|c|}{ LPLex1_C50G } \\
\hline $\mathrm{CC}$ & 137 & $2.29(0.22)^{\mathrm{A}}$ & & $2.64(0.25)^{\mathrm{A}, \mathrm{a}}$ & $2.68(0.25)^{\mathrm{A}}$ \\
\hline $\mathrm{CG}$ & 274 & $2.14(0.18)^{\mathrm{A}}$ & & $2.94(0.22)^{\mathrm{A}, \mathrm{b}}$ & $2.84(0.16)^{\mathrm{A}}$ \\
\hline GG & 1,351 & $1.82(0.17)^{\mathrm{B}}$ & & $3.41(0.22)^{\mathrm{B}}$ & $3.12(0.15)^{\mathrm{B}}$ \\
\hline \multicolumn{6}{|c|}{ SCD3UTR_delTGT } \\
\hline$-1-$ & 255 & $1.56(0.23)^{\mathrm{AB}, \mathrm{a}}$ & $47.3(9.1)^{\mathrm{A}, \mathrm{a}}$ & & \\
\hline TGT/- & 647 & $1.68(0.17)^{\mathrm{A}}$ & $51.9(6.4)^{\mathrm{AB}}$ & & \\
\hline TGT/TGT & 773 & $2.029(0.17)^{\mathrm{B}, \mathrm{b}}$ & $63.1(6.5)^{\mathrm{A}, \mathrm{b}}$ & & \\
\hline
\end{tabular}

Three SNP ( 1 in $A C A C A, 1$ in $L P L$, and 1 in $S C D$ ) were found to be significantly associated with milk production traits (Bonferroni gene-wide adjusted significance level: $P<0.01)$. For brevity, Table 3 reports only the significant effects. The number of daughter phenotypes for each genotype are also specified.

The $\mathrm{C}-\mathrm{T}$ substitution at exon 45 of the $A C A C A$ gene showed an effect on milk yield and fat percentage. Daughters of TT bucks had the lowest average milk yield $(P<0.001)$, producing about 0.3 to $0.25 \mathrm{~L} / \mathrm{d}$ less than the other 2 genotypes, respectively (Table 3) Such a difference was constant along most of lactation $(P<$ 0.05), until approximately 210 DIM (Figure 1, panel A). A large dominance effect was evidenced (Table 4) and could be observed also on lactation curve shape (Figure 1, panel A). The SNP contribution to the variance of milk yield $(2 \%)$ was the lowest among the 3 markers (Table 4).

The SNP located on the first exon of the lipoprotein lipase gene was highly associated with milk yield, with $\mathrm{CC}$ daughters producing $0.50 \mathrm{~L}$ per day more than the GG daughters (Table 3). This genotype had a large allele substitution effect for this trait but no statistically significant dominance was detected (Table 4). Actually, the most favorable genotype was found just for 1 buck (Table 2), even though lactations for more than 135 daughters were available. In any case, the favorable effect of the $\mathrm{C}$ allele was evident also in the heterozygote genotype (Table 3). The difference between GG and the other 2 genotypes was evident throughout most of lactation (Figure 1, panel B; $P<0.01$ until about 180 DIM). Animals with the highest average milk yield exhibited the lowest fat and protein contents (Table 3). Fat percentage showed a rather constant difference among genotypes along the lactation (Figure 1, panel
D), whereas differences for protein content were relevant mainly until about 120 DIM. The contribution of the marker to the variance $\left(r_{S N P}^{2}\right)$ of the fat percentage was the highest observed across traits and markers (Table 4).

A relevant effect could be observed for the TGT deletion located at the UTR of the $S C D$ locus. The homozygote-deleted genotype had average milk and protein yields about $0.5 \mathrm{~L} / \mathrm{d}$ and $16 \mathrm{~g} / \mathrm{d}$ lower, respectively, compared with the TGT/TGT genotype. Also in this case, the effect of genotype was evident for most of lactation, both for milk and protein yields (Figure 1, panels D and E). The contributions of the goat variance to the phenotypic variance of the milk yield and composition $\left(r_{g}^{2}\right)$ was lower than those in previous reports for dairy goats (Analla et al., 1996; Macciotta et al., 2005).

\section{DISCUSSION}

All the considered loci were found to significantly affect milk yield. Effects on fat and protein percentage, and on protein yield were also observed. For each gene, 2 out of 3 possible contrasts were statistically significant, with 1 of the 2 homozygote classes represented by a small number of individuals. The consequence was a higher standard error of the difference. In the present research, only 1 buck was found to be a carrier of the CC genotype for the $L P L$ locus; thus, a confounding between sire and genotype effect was likely to occur. However, the phenotypes were recorded on a large number of daughters. Moreover, the behavior of the other 2 genotypes confirmed the favorable effect of the $\mathrm{C}$ allele on milk yield. Actually, a relevant imbalance between 


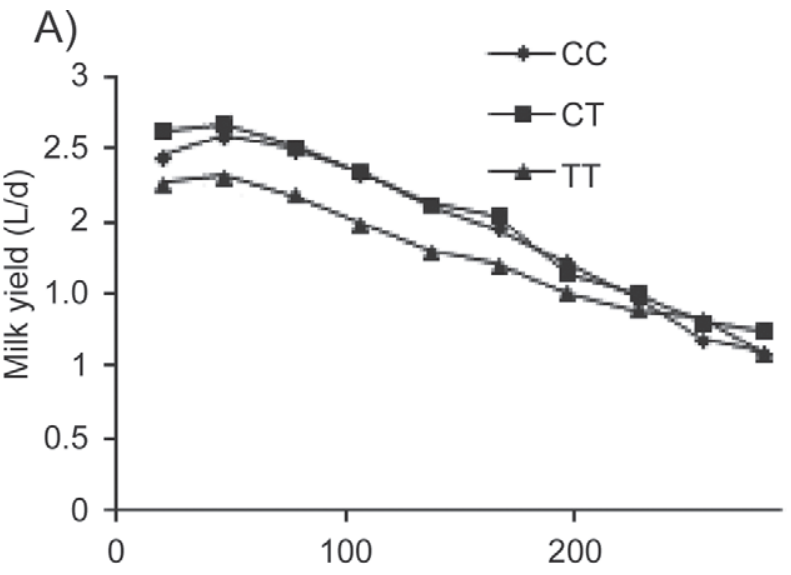

B)

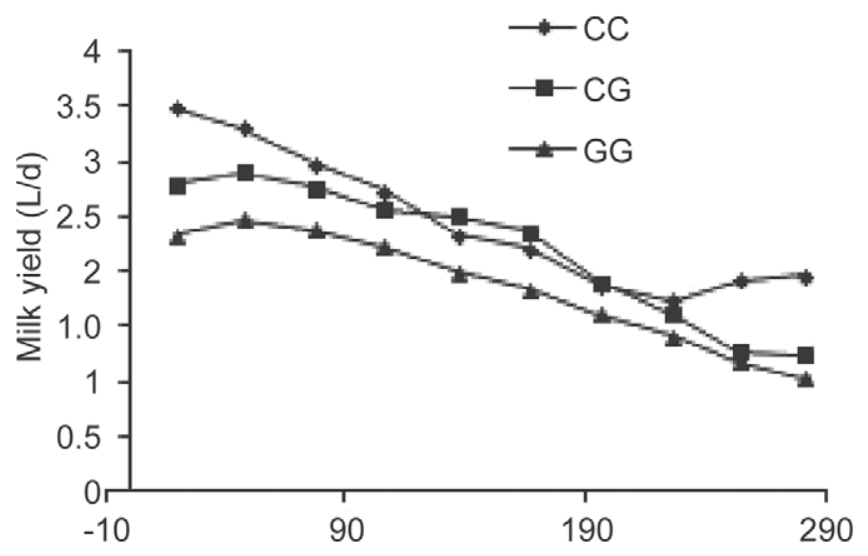

D)

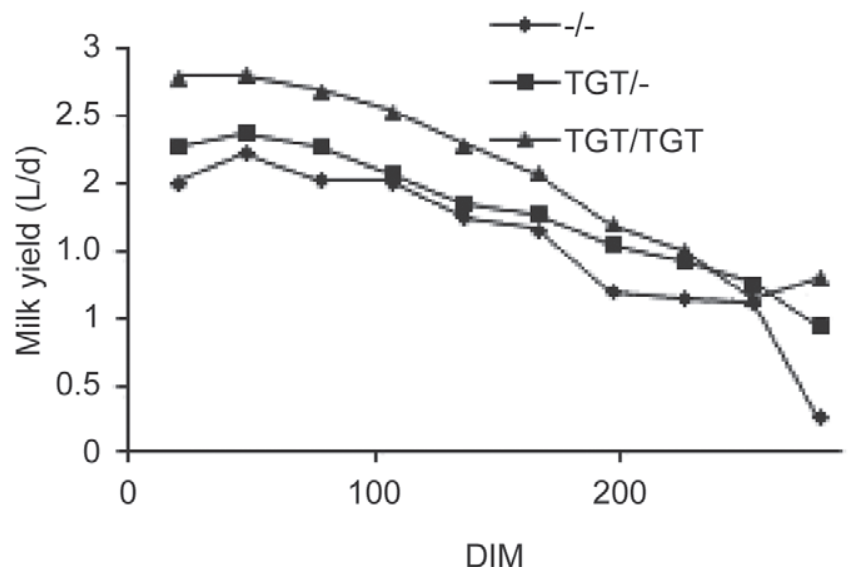

C)

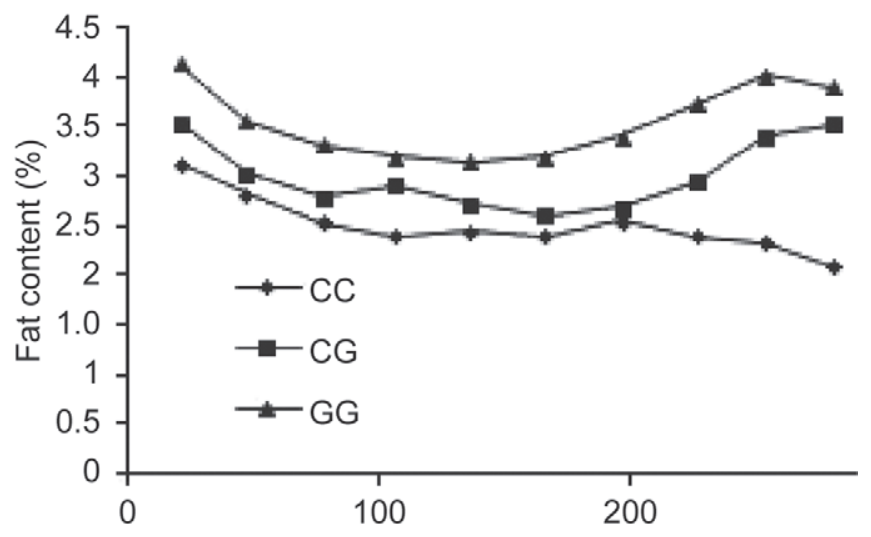

E)

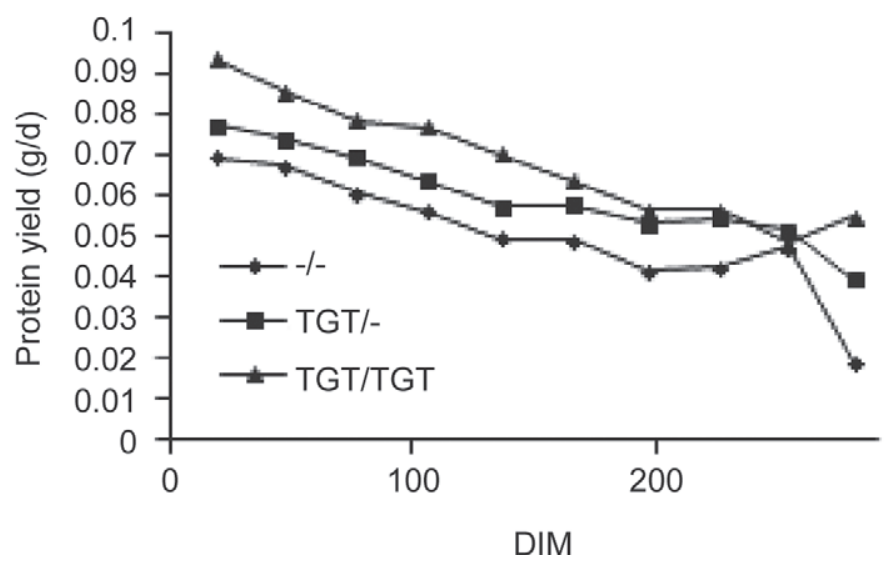

Figure 1. Estimated average lactation curves for milk yield of daughters of bucks with different genotypes at the SNP located at the 45th exon of the acetyl-CoA carboxylase $\alpha$ gene (A), at the fifth exon of the lipoprotein lipase gene (B and C), and at the $3{ }^{\prime}$ untranslated region (UTR) TGT deletion of the stearoyl-CoA desaturase gene (D and E). 
Table 4. Allele substitution effect (mean \pm SE) and contribution of each significant SNP to the total phenotypic variance of milk (MY) and protein (PY) yield, and fat (FP) and protein (PP) percentage

\begin{tabular}{|c|c|c|c|c|c|c|c|}
\hline \multirow[b]{2}{*}{ Variable } & \multirow[b]{2}{*}{$\mathrm{SNP}^{1}$} & \multicolumn{4}{|c|}{ Effect $^{2}$} & \multicolumn{2}{|c|}{$\begin{array}{c}\text { Variance } \\
\text { contribution }^{3}\end{array}$} \\
\hline & & $\alpha$ & $P$-value & $\mathrm{d}$ & $P$-value & $\mathrm{r}_{\mathrm{SNP}}^{2}$ & $\mathrm{r}_{\mathrm{G}}^{2}$ \\
\hline MY (L) & $\begin{array}{l}\text { ACACAex45_CT } \\
\text { LPLex1_C50G } \\
\text { SCD3UTR_delTGT }\end{array}$ & $\begin{array}{r}-0.15 \pm 0.05 \\
-0.23 \pm 0.08 \\
0.23 \pm 0.10\end{array}$ & $\begin{array}{r}<0.01 \\
<0.01 \\
0.01\end{array}$ & $\begin{array}{r}0.12 \pm 0.08 \\
0.09 \pm 0.08 \\
-0.11 \pm 0.10\end{array}$ & $\begin{array}{l}0.01 \\
0.28 \\
0.29\end{array}$ & $\begin{array}{l}0.02 \\
0.04 \\
0.04\end{array}$ & 0.13 \\
\hline $\mathrm{FP}(\%)$ & LPLex1_C50G & $0.38 \pm 0.07$ & $<0.01$ & $-0.09 \pm 0.07$ & 0.23 & 0.07 & 0.05 \\
\hline $\mathrm{PP}(\%)$ & LPLex1_C50G & $0.22 \pm 0.10$ & $<0.05$ & $-0.06 \pm 0.11$ & 0.60 & 0.03 & 0.09 \\
\hline
\end{tabular}

${ }^{1} \mathrm{ACACA}=$ acetyl-CoA carboxylase $\alpha ; \mathrm{LPL}=$ lipoprotein lipase; SCD = stearoyl-CoA desaturase; ex = exon; UTR = untranslated region; del $=$ deletion.

${ }^{2} \alpha=$ substitution effect, expressed in the same units of the corresponding variables; $d=$ dominance effect, expressed in the same units of the corresponding variables.

${ }^{3} \mathrm{r}_{\mathrm{SNP}}^{2}=$ contribution to the variance of SNP genotype and $\mathrm{r}_{\mathrm{G}}^{2}=$ contribution to the variance of individual goat $(\mathrm{G})$ to the total genotypic variance.

genotype frequencies is a common issue in association studies (Giaccone et al., 2000). In a study on MurcianoGranadina goats, for example, no CC individuals were found for LPL (Badaoui et al., 2007). In any case, further validations on larger samples of animals is needed to properly assess the effect of this polymorphism.

The largest effects on milk yield and fat percentage, both in terms of substitution and contribution to the phenotypic variance of the trait, were found for the C50G SNP of the lipoprotein lipase gene. The abovementioned study on Spanish goats reported associations between this polymorphism and milk fat percentage. Results are in agreement with those of the present study both in terms of the favorable allele $(\mathrm{G})$ and of magnitude of the effect (about $0.5 \%$ of difference between least squares means on GC and GG animals in both traits).

The second effect in terms of magnitude was found for the SNP located in the $S C D$ locus. A previous report on Spanish goats indicated an association between this polymorphism and lactose content and also with milk FA composition (Zidi et al., 2010). In particular, goats homozygous for the deletion showed the highest content of PUFA and total conjugated linoleic acid. In the present study, this genotype was characterized by the lowest milk yield. The comparison of these results, even with all the care needed when considering reports of different studies, may suggest a mechanism similar to what was observed in dairy cattle, where the genotype for an $S C D$ mutation with the highest milk yield showed the lowest desaturase activity (Mele et al., 2007; Macciotta et al., 2008). Moreover, $S C D$ was also found to affect protein yield in cows, as in the case of the present study. Zidi et al. (2010) suggested that the TGT dele- tion produces a conformational change in the mRNA secondary structure, promoting the formation of a long stacked pair terminated in 2 small hairpin loops. Finally, this polymorphism showed an effect on milk and protein yield of the same sign. A similar effect on milk and protein yields has been reported in cattle for the $S C D$ and diacylglycerol acyltransferase (DGAT1) loci (Kühn et al., 2004; Macciotta et al., 2008). This result is of interest because usually genotypes with favorable effects on milk yield negatively affect milk composition.

The C-T substitution at exon 45 of the $A C A C A$ locus had already been identified in a study carried out on Spanish goat breeds (Badaoui et al., 2007), where the authors found associations between this polymorphism and milk fat, lactose content, and SCC. In the current study, the presence of this polymorphism was confirmed also in the Italian goat breed analyzed, showing an effect on milk yield. The mutation that was genotyped is silent; consequently, it is not expected to change the structure of the encoded enzyme, suggesting that this polymorphism could be linked to other mutations influencing these traits.

The amount of data available for the analysis was larger than usual association studies in small ruminants. This was because of the choice of using daughter performances of genotyped bucks for assessing the gene effect. As a result, the estimated effect is expected to be reduced but it could be compensated by the larger number of records available. Moreover, using directly goat performances, the analysis was carried out under a longitudinal perspective, considering repeated records for each individual across the lactation. Such an approach, already used in goats to map QTL (Roldán et al., 2008), allows for an evaluation of the gene effect 
in different stages of lactation. It is widely assessed that the use of test-day measures instead of a single cumulated yield allows for a better estimation of fixed effects considered in the model. In the case of the $D G A T 1$ locus in cattle, the effect of the genotype was reported to be evident at $40 \mathrm{~d}$ of lactation (Strucken et al., 2011). In the present study, differences between genotypes were quite constant across most of lactation.

If confirmed by other studies, results here obtained could supply useful information for the genetic improvement of milk traits in the Alpine breed and in other goat breeds. The 3 considered candidate loci could be added to the pool of genes of potential interest for gene assisted selection programs in goats, the most known example of which is represented by the casein cluster (Hayes et al., 2006; Gama and Bressan, 2011). In recent years, the availability of high-throughput SNP platforms has enabled the implementation of genomic selection programs in dairy cattle (VanRaden et al., 2009). A high-density SNP platform is already available for sheep and it has just been presented by an international goat consortium (Tosser-Klopp and IGGC, 2012) for goats, opening perspectives of genomic selection also for this species. Mutations at candidate genes, as those reported in this study, could be implemented in the SNP chip to enhance its efficiency in genomic selection. This the case, for example, of the GeneSeek Genomic Profiler for Dairy Cattle (http://www.neogen. com/GeneSeek/pdf/Catalogs/DairyGenomicProfiler. pdf), obtained by adding to the 7K BeadChip (Illumina Inc., San Diego, CA) some SNP for single-gene tests, detecting haplotypes that affect fertility, and parentage validation (Wiggans et al., 2012).

\section{CONCLUSIONS}

Associations between 3 polymorphisms at candidate genes analyzed and dairy traits have been found in Alpine goats farmed in Italy. Two markers were already reported in the literature and one was discovered in the present work. These associations, which should be tested in a larger sample especially for those markers that show rare genotypes, may offer useful indications for the development of gene-assisted programs for the improvement of dairy traits in this species. These perspectives could be further enhanced by the next commercial availability of a high-throughput SNP platform for the genotyping of tens of thousands of SNP markers for this species.

\section{ACNKOWLEDGEMENTS}

This research was supported by the Ministero Politiche Agricole Alimentati e Forestali (MIPAF) Sel- mol and Innovagen projects. The authors thank the coordinators of the project A. Nardone, A. Valentini, and L. Ramunno and the National Association of Goat and Sheep Breeders (ASSONAPA, Rome, Italy) for providing hair samples and phenotypic data.

\section{REFERENCES}

Analla, M., I. Jiménez-Gamero, A. Muñoz-Serrano, J. M. Serradilla, and A. Falagán. 1996. Estimation of genetic parameters for milk yield and fat and protein contents of milk from Murciano-Granadina goats. J. Dairy Sci. 79:1895-1898.

Badaoui, B., J. M. Serradilla, A. Tomàs, B. Urrutia, J. L. Ares, J. Carrizosa, A. Sànchez, J. Jordana, and M. Amills. 2007. Goat acetyl-coenzyme A carboxylase $\alpha$ : Molecular characterization, polymorphism, and association with milk traits. J. Dairy Sci. 90:1039-1043.

Banos, G., J. A. Woolliams, B. W. Woodward, A. B. Forbes, and M. P. Coffey. 2008. Impact of single nucleotide polymorphisms in leptin, leptin receptor, growth hormone receptor, and diacylglycerol acyltransferase (DGAT1) gene loci on milk production, feed, and body energy traits of UK dairy cows. J. Dairy Sci. 91:3190-3200.

Bauman, D. E., I. H. Mather, R. J. Wall, and A. L. Lock. 2006. Major advances associated with the biosynthesis of milk. J. Dairy Sci. 89:1235-1243.

Bernard, L., C. Leroux, H. Hayes, M. Gautier, Y. Chilliard, and P. Martin. 2001. Characterization of the caprine stearoyl-CoA desaturase gene and its mRNA showing an unusually long 3'-UTR sequence arising from a single exon. Gene 281:53-61.

Bionaz, M., and J. J. Loor. 2008. Gene networks driving bovine milk fat synthesis during the lactation cycle. BMC Genomics 9:366.

Caravaca, F., J. L. Ares, J. Carrizosa, B. Urrutia, F. Baena, J. Jordana, B. Badaoui, A. Sànchez, A. Angiolillo, M. Amills, and J. M. Serradilla. 2011. Effects of $\alpha_{\mathrm{s} 1}$-casein $(C S N 1 S 1)$ and $\kappa$-casein (CSN3) genotypes on milk coagulation properties in MurcianoGranadina goats. J. Dairy Res. 78:32-37.

Chen, Z., J. Sun, Z. Li, X. Lan, C. Zhang, Y. Qu, Y. Liu, X. Fang, C. Lei, and H. Chen. 2011. Novel SNP in the caprine stearoylCoA desaturase $(S C D)$ and decorin $(D C N)$ genes that are associated with growth traits in Chinese goat breeds. Mol. Biol. Rep. 38:3121-3127.

Chiatti, F., S. Chessa, P. Bolla, C. Cigalino, A. Caroli, and G. Pagnacco. 2007. Effect of $\kappa$-casein polymorphism on milk composition in the Orobica goat. J. Dairy Sci. 90:1962-1966.

Cohen-Zinder, M., E. Seroussi, D. M. Larkin, J. J. Loor, A. Everts-van der Wind, J. H. Lee, J. K. Drackley, M. R. Band, A. G. Hernandez, M. Shani, H. A. Lewin, J. I. Weller, and M. Ron. 2005. Identification of a missense mutation in the bovine $A B C G 2$ gene with a major effect on the QTL on chromosome 6 affecting milk yield and composition in Holstein cattle. Genome Res. 15:936-944.

FAO (Food and Agriculture Organization of the United Nations). 2007. The State of the World's Animal Genetic Resources for Food and Agriculture. B. Rischkowsky and D. Pilling, ed. FAO, Rome, Italy.

Gama, L. T., and M. C. Bressan. 2011. Biotechnology applications for the sustainable management of goat genetic resources. Small Rumin. Res. 98:133-146.

Giaccone, P., L. Di Stasio, N. P. P. Macciotta, B. Portolano, M. Todaro, and A. Cappio-Borlino. 2000. Effect of $\beta$-lactoglobulin polymorphism on milk-related traits of dairy ewes analyzed by a repeated measures design. J. Dairy Res. 67:443-448.

Grisart, B., W. Coppieters, F. Farnir, L. Karim, C. Ford, P. Berzi, N. Cambisano, M. Mni, S. Reid, P. Simon, R. Spelman, M. Georges, and R. Snell. 2002. Positional candidate cloning of a QTL in dairy cattle: Identification of a missense mutation in the bovine DGAT1 gene with major effect on milk yield and composition. Genome Res. 12:222-231.

Hayes, B., N. Hagesæther, T. Ådnøy, G. Pellerud, P. R. Berg, and S. Lien. 2006. Effects on production traits of haplotypes among casein genes in Norwegian goats and evidence for a site of preferential recombination. Genetics 174:455-464. 
Ibeagha-Awemu, E. M., P. Kgwatalala, and X. Zhao. 2008. A critical analysis of production-associated DNA polymorphisms in the genes of cattle, goat, sheep and pig. Mamm. Genome 19:591-617.

Jenkins, T. C., and M. A. McGuire. 2006. Major advances in nutrition: Impact on milk composition. J. Dairy Sci. 89:1302-1310.

Kühn, C., G. Thaller, A. Winter, O. R. P. Bininda-Emonds, B. Kaupe, G. Erhardt, J. Bennewitz, M. Schwerin, and R. Fries. 2004. Evidence for multiple alleles at the DGAT1 locus better explains a quantitative trait locus with major effect on milk fat content in cattle. Genetics 167:1873-1881.

Littell, R. C., P. R. Henry, and C. B. Ammerman. 1998. Statistical analysis of repeated measures data using SAS procedures. J. Anim. Sci. 76:1216-1231.

Liu, K., and S. V. Muse. 2005. PowerMarker: Integrated analysis environment for genetic marker data. Bioinformatics 21:2128-2129.

Macciotta, N. P. P., P. Fresi, G. Usai, and A. Cappio-Borlino. 2005 Lactation curves of Sarda breed goats estimated with test day models. J. Dairy Res. 72:470-475.

Macciotta, N. P. P., M. Mele, G. Conte, A. Serra, M. Cassandro, R. Dal Zotto, A. Cappio Borlino, G. Pagnacco, and P. Secchiari. 2008. Association between a polymorphism at the stearoyl CoA desaturase locus and milk production traits in Italian Holsteins. J. Dairy Sci. 91:3184-3189.

Mele, M., G. Conte, B. Castiglioni, S. Chessa, N. P. P. Macciotta, A. Serra, A. Buccioni, G. Pagnacco, and P. Secchiari. 2007. StearoylCoA desaturase gene polymorphism and milk fatty acids composition in Italian Holsteins. J. Dairy Sci. 90:4458-4465.

Moioli, B., G. Contarini, A. Avalli, G. Catillo, L. Orrù, G. De Matteis, G. Masoero, and F. Napolitano. 2007a. Effect of stearoyl coenzyme A desaturase polymorphism on fatty acid composition of milk. J. Dairy Sci. 90:3553-3558.

Ntambi, J. M., and M. Miyazaki. 2004. Regulation of stearoyl-CoA desaturases and role in metabolism. Prog. Lipid Res. 43:91-104.

Ohsaki, H., A. Tanaka, S. Hoashi, S. Sasazaki, K. Oyama, M. Taniguchi, F. Mukai, and H. Mannen. 2009. Effect of SCD and SREBP genotypes on fatty acid composition in adipose tissue of Japanese Black cattle herds. Anim. Sci. J. 80:225-232.

Pauciullo, A., G. Cosenza, R. Steri, A. Coletta, L. Jemma, M. Feligini, D. Di Berardino, N. P. P. Macciotta, and L. Ramunno. 2012. An association analysis between OXT genotype and milk yield and flow in Italian Mediterranean river buffalo. J. Dairy Res. 79:150-156

Roldán, D. L., A. E. Rabasa, S. Saldaño, F. Holgado, M. A. Poli, and R. J. Cantet. 2008. QTL detection for milk production traits in goats using a longitudinal model. J. Anim. Breed. Genet. 125:187-193

Signorelli, F., F. Napolitano, G. De Matteis, M. C. Scatà, G. Catillo, C. Tripaldi, and B. Moioli. 2009. Identification of novel single nucleotide polymorphisms in promoter III of the acetyl-CoA carboxylase- $\alpha$ gene in goats affecting milk production traits. J. Hered. 100:386-389.
Stanton, T. L., L. R. Jones, R. W. Everett, and S. D. Kachman. 1992 Estimating milk, fat, and protein lactation curves with a test day model. J. Dairy Sci. 75:1691-1700.

Strucken, E. M., D. J. de Koning, S. A. Rahmatalla, and G. A. Brockmann. 2011. Lactation curve models for estimating gene effects over a timeline. J. Dairy Sci. 94:442-449.

Tosser-Klopp, G., and IGGC (International Goat Genome Consortium). 2012. Goat genome assembly, Availability of an international 50K SNP chip and RH panel: An update of the International Goat Genome Consortium projects. Plant and Animal Genome (PAG) meeting, San Diego, CA. Accessed Jan. 4, 2012. http://www.otago.ac.nz/crg/publications/science/otago031074. html\# conference.

Travers, M. T., and M. C. Barber. 1993. Isolation of a goat acetyl-CoA carboxylase complementary DNA and effect of milking frequency on the expression of the acetyl-CoA carboxylase and fatty acid synthase genes in goat mammary gland. Comp. Biochem. Physiol. B 105:123-128.

VanRaden, P. M., C. P. Van Tassell, G. R. Wiggans, T. S. Sonstegard, R. D. Schnabel, J. F. Taylor, and F. S. Schenkel. 2009. Invited review: Reliability of genomic predictions for North American Holstein bulls. J. Dairy Sci. 92:16-24.

Weller, J. I., Y. Kashi, and M. Soller. 1990. Power of daughter and granddaughter designs for determining linkage between marker loci and quantitative trait loci in dairy cattle. J. Dairy Sci. $73: 2525-2537$.

Wiggans, G. R., P. M. VanRaden, T. A. Cooper, C. P. Van Tassell, T. Sonstegard, and B. Simpson. 2012. Characteristics and use of the Illumina BovineLD BeadChip. J. Dairy Sci. 95(Suppl. 2):450. (Abstr.)

Yahyaoui, M. H. 2003. Genetic polymorphism in goat. PhD Thesis Universidad Autonoma de Barcelona, Facultad de Veterinaria, Barcelona, Spain.

Yahyaoui, M. H., A. Sanchez, and J. M. Folch. 2002. Partial nucleotide sequence of the goat stearoyl coenzyme A desaturase cDNA and gene structure. J. Anim. Sci. 80:866-867.

Yahyaoui, M. H., D. Vaiman, A. Sánchez, and J. M. Folch. 2003. Mapping of the goat stearoyl coenzyme A desaturase gene to chromosome 26. Anim. Genet. 34:474-475.

Zhang, C.-L., X.-Y. Gao, R.-Y. Shao, Y.-H. Wang, X.-T. Fang, and H. Chen. 2010. Stearoyl-CoA desaturase $(S C D)$ gene polymorphism in goat breeds. Biochem. Genet. 48:822-828.

Zidi, A., V. M. Fernández-Cabanás, B. Urrutia, J. Carrizosa, O. Polvillo, P. González-Redondo, J. Jordana, D. Gallardo, M. Amills, and J. M. Serradilla. 2010. Association between the polymorphism of the goat stearoyl-CoA desaturase 1 (SCD1) gene and milk fatty acid composition in Murciano-Granadina goats. J. Dairy Sci 93:4332-4339. 